\title{
Pedagogical preparation of nursing professors for professional secondary technical education
}

\author{
Preparo pedagógico de enfermeiros docentes para educação profissional técnica de nível médio \\ Preparación pedagógica de enfermeros docentes para la educación profesional de nivel médio
}

\section{Daniela Maysa de Souza', Vânia Marli Schubert Backes', Daniele Delacanal Lazzari', Jussara Gue Martini' \\ ' Universidade Federal de Santa Catarina. Florianópolis, Santa Catarina, Brazil.}

\section{How to cite this article:}

Souza DM, Backes VMS, Lazzari DD, Martini JG. Pedagogical preparation of nursing professors for professional secondary technical education. Rev Bras Enferm [Internet]. 2018;71(5):2432-9. DOI: http://dx.doi.org/10.1590/0034-7167-2017-0289

\author{
Submission: 05-04-2017 Approval: 05-06-2018
}

\begin{abstract}
Objective: To understand how the nursing professor pedagogically prepares for teaching in professional secondary technical education in the light of the Pedagogical Content Knowledge of Lee S. Shulman. Method: This is a qualitative and descriptive study. Two pedagogical workshops were held to collect data, with the participation of six professors from two technical schools. Results: The categories Pedagogical preparation for the teaching exercise and Knowledge Base for Teaching have emerged. The results revealed the difference between the real and the ideal in the perception of the participants, when their preparation for the teaching exercise is situated between the learning with colleagues and the mastery over the Content Knowledge. Final considerations: Professor training is necessary and is an alternative to qualify teaching in professional secondary technical education.
\end{abstract}

Descriptors: Nursing Education; Nursing Professors; Practice of the Nursing Professor; Research in Nursing Education; Technical Education in Nursing.

\section{RESUMO}

Objetivo: Compreender como o professor enfermeiro se prepara pedagogicamente para a docência na educação profissional técnica de nível médio à luz do Conhecimento Pedagógico do Conteúdo de Lee S. Shulman. Método: Trata-se de um estudo qualitativo e descritivo. Para coleta de dados foram realizadas duas oficinas pedagógicas, com a participação de seis docentes de duas escolas técnicas. Resultados: Duas categorias emergiram: Preparo pedagógico para o exercício docente e Conhecimento Base para o Ensino. Os resultados revelaram a diferença entre o real e o ideal na percepção dos participantes, quando seu preparo para o exercício docente se situa entre a aprendizagem com colegas e o domínio sobre o Conhecimento do Conteúdo. Considerações finais: A formação docente é necessária e constitui-se numa alternativa para qualificação do ensino na educação profissional técnica de nível médio.

Descritores: Educação em Enfermagem; Docentes de Enfermagem; Prática do Docente de Enfermagem; Pesquisa em Educação de Enfermagem; Educação Técnica em Enfermagem.

\section{RESUMEN}

Objetivo: Comprender cómo el profesor enfermero se prepara pedagógicamente para la docencia en la educación profesional técnica de nivel medio a la luz del conocimiento pedagógico del contenido de Lee S. Shulman. Método: Se trata de un estudio cualitativo y descriptivo. Para la recolección de datos se realizaron dos talleres pedagógicos, con la participación de seis docentes de dos escuelas técnicas. Resultados: Dos categorías emergieron: Preparación pedagógica para el ejercicio docente y Conocimiento Base para la Enseñanza. Los resultados revelaron la diferencia entre lo real y lo ideal en la percepción de los participantes, cuando su preparación para el ejercicio docente se sitúa entre el aprendizaje con colegas y el dominio sobre el Conocimiento del Contenido. Consideraciones finales: La formación docente es necesaria y se constituye en una alternativa para la cualificación de la enseñanza en la educación profesional técnica de nivel medio.

Descriptores: Educación en Enfermería; Docentes de Enfermería; Práctica del Docente de Enfermería; Investigación en Educación de Enfermería; Educación Técnica en Enfermería. 


\section{INTRODUCTION}

Nurses often approach teaching early in their professional life, or even later, after a few years of caregiving activities. The professional secondary technical education represents a broad field of action for those who opt for teaching, in addition to the responsibilities arising from the vertical division of nursing work (teaching activities, supervision and management of the care team) $)^{(1)}$.

For the training of mid-level providers to commit themselves to the logic of service organization, it is necessary to advance and improve the pedagogical training of nurses in order to qualify pedagogical planning and, consequently, to strengthen the articulation between theory and practice ${ }^{(2-3)}$.

The years of teaching allow the following classification (independently of the assistance experience): one is considered beginner the professor with experience of one to five years; intermediary, those who work from six to fourteen years and experienced those who have been working for more than fifteen years ${ }^{(4-5)}$.

New professors entering the classroom early require special attention because, for part of the nurses who teach (especially considering those who did not have a degree through the Nursing Degree), the pedagogical training is vague and superficial, not allowing from the beginning of his/her teaching career ${ }^{(1)}$.

Concerned with professor training and performance, educational psychologist Lee Shulman popularized the expression "Pedagogical Content Knowledge", supporting in his/her theory that the knowledge considered as the basis for the teaching exercise are: content knowledge, general pedagogical knowledge, curriculum knowledge, Pedagogical Content Knowledge (PCK), knowledge about students and their characteristics, knowledge of the educational context and knowledge of the aims, purposes, educational values and their philosophical and historical basis ${ }^{(6)}$.

This knowledge base, built in different moments and contexts, is related to the different teaching experiences and personal, academic and professional routes. PCK stands out because it is a personal construction of the professor, in which his/her experiences and his/her knowledge merge and summon all other components of the knowledge base, demonstrating in practice, a particular conception of teaching. The PCK is a mix of content and pedagogy, being the individual manifestation of the professor, of his/her knowledge for teaching, that is, his/her ability to transform the incomprehensible into comprehensible, using forms pedagogically adaptable to the diverse needs of the students ${ }^{(7)}$.

In this broad context that encompasses professor education and how it transforms content into learning for the student, it is reflected on how professor education policies should enable moments of reflective and meaningful learning. The need for pedagogical preparation to practice teaching begins with the reflection on the teaching practice, in this way, it was sought to know how the pedagogical preparation for the teaching exercise occurs and how the professor seeks to qualify for the exercise in professional secondary technical education, besides knowing the needs pointed out by the nurses, related to the pedagogical preparation.

\section{OBJECTIVE}

To understand how nursing professors pedagogically prepares for teaching in professional secondary technical education in the light of the Pedagogical Content Knowledge of Lee S. Shulman.

\section{METHOD}

\section{Ethical aspects}

This study was approved by the Research Ethics Committee of the Universidade Federal de Santa Catarina. Participants were identified by the letter $\mathrm{P}$ (of professor), followed by the number corresponding to the order of participation in the workshops. All participants signed the Informed Consent Form, in order to comply with the ethical principles of the research, as recommended by Resolution 466 of the National Health Council (Conselho Nacional de Saúde).

\section{Type of study}

This is a descriptive qualitative research, excerpt from the master's dissertation titled "Preparation of nurses for teaching in professional secondary technical education from the perspective of Lee Shulman", which had as a research question: how do nursing professor of professional secondary technical education prepares for teaching and how it improves its practice?

\section{Setting and study participants}

The research was carried out with nursing professors of technical courses of two professional secondary technical education schools of a city in the southern region of Brazil, chosen according to the principal researcher to work in both institutions. All the professors who worked in the two schools (nine in total) were contacted in person and by electronic mail to participate in the study, of which six professors agreed to participate, with three participants from each school.

Participants met the proposed inclusion criteria, which was to be a nurse and to be working in professional secondary technical education teaching. Professors on vacation or under health leave of absence were excluded in the period for data collection.

\section{Collection and data organization}

Data collection was carried out in the premises of one of the schools participating in the study and was carried out through two pedagogical workshops held in two meetings of approximately three hours each, held between April and May 2013.

The two workshops (presented below) are characterized as an intentional sample, believing that they were adequate to obtain the intentional information, resulting from the data collection.

In the first pedagogical workshop, the study proposal was presented, explaining the relevance of the theme and consequent contribution to the improvement and reflection of the teaching practice, from the perspective of Lee S. Shulman. It was proposed an activity to present the participants' professional trajectory, containing the history of the training and teaching performance, offering subsidies to the researcher to characterize the profile of the participants and knowledge of their training for the teaching exercise. At this meeting, two questioning 
questions were also discussed: "How did I prepare myself to practice teaching?" and "How do I believe I should or should have prepared me to practice teaching?" With a later collective discussion about the pedagogical preparation for teaching, being at that moment, briefly inserted the theoretical reference of Lee Shulman on the Base Knowledge for Teaching, especially the PCK and its respective sources, finishing the meeting with the indication of reading to the next meeting.

In the second pedagogical workshop, Lee Shulman recorded a video interview in which the author presents obstacles and challenges for the training of creative, intelligent and problem-solving students. At the end of the projection, participants were asked to share the reflections from the video and the proposed theoretical framework was explained, encouraging dialogue among the participants. Subsequently, the recommended readings for presentation and contextualization of each participant's understanding were discussed. The subsequent contextualization of the researcher on the Base Knowledge for Teaching (in particular the PCK) sought to relate them to the preparation for teaching of the participants, rescuing the productions and the memories produced in the workshops, so that in a group, through the reflection provided, it was possible to recognize the participants' understanding.

Participants' statements were transcribed and subsequently validated individually, sent by electronic mail.

\section{Data analysis}

Thematic analysis took place in three stages. In the first one, called pre-analysis, the field material was read to understand the particularities and elaboration of assumptions for analysis and interpretation of the material, constituting the corpus by means of the representativity of the obtained data, determining the cuts, the categorization form and the general theoretical concepts that guided the analysis ${ }^{(8)}$.

In the second stage, exploration of the material, a new reading was made, identifying, through inferences, the nuclei of meaning and analyzing them, searching for broad themes for discussions, elaborating a writing by theme, in order to give account of the senses which guided the analysis ${ }^{(8)}$. From this process emerged the themes and data that were analyzed and associated in the light of the Shulman PCK, knowing the congruence of the obtained results, purifying this material in a way that emerged unifying logics sustained by the proposed theoretical reference.

In the third stage of treatment of the obtained results and interpretation, an interpretative synthesis was elaborated, through a writing that dialogued subjects with the objective, question and presuppositions of the research ${ }^{(8)}$.

For the analysis of the data, a table was used to record in full the transcriptions of the participants' speech, divided by themes. After a new reading of the material, the classification and distinction by color were performed, identifying the convergent, divergent or singular answers. Afterwards, the clipping of these lines and grouping by categories, the definition of subcategories was allowed.

\section{RESUITS}

Participants were between 30 and 50 years old and had been trained for five and 15 years. With regard to the degree, four had baccalaureate in nursing and two graduates in nursing. Regarding the qualification Lato sensu and Stricto sensu, all had specialization in different areas and three participants were studying Master in Education. With regard to the beginning of teaching activities, all the participants mentioned that they had received an invitation from the course coordinators to start their activities in the Nursing Technical course and began their teaching, covering the period from one to five years after graduation, without previous preparation for the teaching exercise.

As a motivating factor for the beginning of the teaching activity, three participants mentioned the complementation of income. For another participant, the choice for teaching was due to the fact of adding new skills to professional development, such as communication and interaction with people. For another, the motivating factor was the desire to share their technical and scientific knowledge to improve nursing care. For one participant, teaching came as an option in substitution for assistance activities and for another participant, teaching was reported as vocation and mission, having opted directly for teaching, without acting in the assistance.

From the workshops, the data collected allowed the definition of two categories: Absence of pedagogical preparation for the teaching exercise; and Base knowledge for teaching.

Absence of pedagogical preparation for the teaching exercise

The preparation for the teaching exercise and the strategies found by the participants to qualify their practice appeared as a concern related to the improvement of teaching as a specific activity, craft or profession, only after the insertion in teaching. From the reflections of the participants, observations related to the field of scientific technical content arose, as they considered that it provides safety and resourcefulness in the classroom. They also considered that when they were included in teaching, the scientific background could overcome the lack of methodological mastery and strategies of teaching learning.

I prepared myself for teaching by seeking scientific technical knowledge and common sense. So, I could act I prepared myself with full scientific technical knowledge. Being sure that what I was talking about was true sovereign and common sense was what helped me in handling classroom situations. (P1)

I obviously studied all my technical contents for those moments with the students, but from the pedagogical point of view, there was no preparation. (P2)

The experiences of the participants when they were still students, based on examples of teaching, were repeated and used to guide their pedagogical practices, indicating that they exerted a significant influence on their pedagogical attitudes.

When I started teaching I didn't prepare myself. You consider yourself a good technique, so automatically, you are able to teach. I didn't prepare myself, it was all based on experiences. (P2)

If there is no initial baseline, it develops. And then, as the individual discerns what is right or wrong, his/her practices will be assertive or not. If I only liked the banking classes, in 
which the professor spoke and I answered, I would become a professor with that same attitude. So, what I used as a personal strategy was just the examples I had in my life, so I tried to prepare classes that I thought would be nice to me, the way I could learn. (P1)

The participants of this study reported that they have constantly resorted to the help of colleagues to strengthen pedagogical practice through the socialization of pedagogical practices considered successful.

And then as time passed by, then came the exchanges, meeting other people, we exchanged many experiences as professors. (P1)

The participation in pedagogical training was considered necessary for specific training in this area and the participants believed that the training should be carried out before the beginning of the teaching exercise. The pedagogical follow-up was also cited as an important activity.

For me it was very important [to participate in training], because I was newly graduated and I got a kind of support, to know which way I had to go and what strategies I had to use. (P3)

I was given a graduate degree from PROFAE [Projeto de Profissionalização dos Trabalhadores da Área de Enfermagem], this was the moment when I really expanded my knowledge. This course gave me the learning of the use of several methods of teaching learning. So I've been using and improving these until today. (P4)

The participants pointed out that, attending specific courses, especially those related to didactics or professor training, also constituted a pedagogical preparation for teaching.

My preparation for teaching took place in the classroom and during the masters training courses. It was when I began to glimpse what it is to be a teacher, what it is to be a professor, the importance of methodologies. I started to have this contact with the pedagogical part of teaching. (P5)

These strategies used for the strengthening and qualification of the teaching practice demonstrate the concern with the professional growth, coming from the professor reflection of the own praxis.

\section{Base knowledge for teaching}

This category addresses the needs pointed out by the participants related to the pedagogical preparation for teaching and the main difficulties encountered in this context. Some observations appeared as facilitators for the teaching exercise, such as: to know the proposal of teaching methodology used by the institution, to receive feedback of its pedagogical practice, to carry out pre-teaching professor training and to carry out pedagogical follow-up activities during the teaching exercise.

Participants, aware of individual responsibilities, believe that, in addition to continuing education, the institution needs to encourage the professor, providing him/her with conditions for his/her continuous improvement.
I believe that today's schools should be concerned about maintaining a continuing education program. Because the preparation of a professor never ends, the professor is not static, the professor must be continually recycling himself/ herself. (P4)

Participants stated that it is essential to know the Political Pedagogical Project (PPP) to understand the institution's objectives and to understand how to conduct daily institutional referrals.

When I started it was like this: this is your discipline and your schedule is this one. You don't know the content, which has already been taught to the student. I miss it, I realize this need for clarity regarding the objectives and proposals of the teaching plan. (P5)

I believe that the proposal of the institution should first be presented to the professor. Because sometimes you will have attitudes without knowing if they are consistent with what the school would like you to do. (P5)

One of the participants reported that undergraduate degree should prepare nurses for teaching.

I think we should be prepared during undergraduate course, because we have a great space, a great time. I believe it would be fundamental to complete undergraduate education and also be prepared to teach others. (P6)

However, the other participants disagreed and affirmed that the undergraduate degree may, somehow punctual, help in the professor training, but they believe that the time is insufficient. It was considered the extensive knowledge necessary for teaching, which cannot be apprehended at the undergraduate level, and it is the responsibility of the provider to improve the knowledge required for teaching. There is, therefore, the awareness that undergraduate education subsidizes the initial practice, and continuous improvement is necessary to strengthen the pedagogical practice, with subsequent improvement of the resourcefulness in the classroom.

One of the difficulties listed by the participants as having been found in their teaching trajectory is related to the absence of training for the use of active learning methodologies and the encouragement to student reflection.

It's difficult, it was difficult. But I felt the greatest difficulty when I started working exclusively with active methodologies. Really expect the student to bring in, expect the student's insight. For me, it was very difficult, precisely because I am very anxious and I wanted to give the question and the answer. (P1)

The pedagogical attitude towards student reflection was a frequent concern among the participants, who reported feeling insecure due to the students' possible productions and questioning about contents that they did not know or did not dominate.

You putting the student to reflect and to speak brings a great insecurity to us, because maybe he/she will address something 
that I am not prepared for. It makes us leave our comfort zone. The student presents something and you see that what you are teaching they have not absorbed, this is so frustrating, that it may be much more comfortable for me to keep going, that I still think maybe they will absorb something. Only you realize that either our education is still very far, and they don't have that preparation to absorb through their activities, or I still have a wrong didactics. (P5)

They also pointed out the anguish related to the student's difficulty in understanding the use of active methodologies.

Yes, it seems they hate to produce. The active methodology for them is a waste of time. (P2)

We have to develop the content that is proposed, but at the same time the students were not oriented that will be worked in a certain way, with active methodology, they also need to seek knowledge. Because sometimes you give a type of work or research to be done and they complain that others don't do so. There is this conflict, and the students still evaluate the professors for how much he/she gave photocopies to them, and then they don't need to make any research as the professor gave in writing. (P5)

These students come with a cradle mentality, school education, banking. Because when I was a student, I have already thought that using active methodology was wasting time, because I had never been explained the intentions, goals. From the moment I had this knowledge, I began to work with students in this way, making an agreement. (P1)

If we reflect on the students who have passed through us and those who are still with us, they are not prepared to be reflective. They want everything ready, when we ask why about anything, they get angry, questioning if it is not the professor who has to give the answer! (P2)

They reinforced that they always carry out the orientation that the student is a participant in the teaching-learning process, responsible for seeking and building knowledge, and believe that when the student is not sensitized to work with this type of method, there are conflicts.

\section{DISCUSSION}

The Content Knowledge to be taught is the starting point for the pedagogical practice, when the professor understands the content to be taught, relating it with other theoretical disciplinary knowledge necessary for teaching. Thus, it exerts a central place in the knowledge base for teaching, with great influence in the pedagogical practice, because the knowledge, or the lack of it, determines the selection of the contents, strategies and materials for the teaching, which ends up determining the conduction of a discipline and the consequent expression of the professor's PCK ${ }^{(9)}$.

In this way, the teaching process begins when the professor understands the content and how it should be taught ${ }^{(10)}$. On the other hand, requiring only mastery of content for the teaching exercise reinforces the idea that teaching is taught by learning and that there is no need for deliberate formal training. This idea also reinforces the perception that specialists in their field are excellent professors, which is not true, since the inefficiency of the specialists in their contents (university professors and researchers) in the classroom is one of the main complaints of students $^{(11)}$, which demonstrates that only Content Knowledge does not enable them to practice successfully.

The domain of content is undoubtedly an essential part of teaching activity, but it does not exclude or replace the need to develop other domains, such as pedagogical ones, which largely constitute a professor's "doing"(12). It is necessary that the nursing professors become aware that only the experience resulting from the practical assistance activity does not support the teaching activity, since they are distinct activities ${ }^{(13)}$.

By connecting Content Knowledge to pedagogical knowledge, the expression of the professor's PCK is observed, when the professor is able to transform his/her personal understanding of content into strategies that enable student learning. And, with only a multifaceted understanding of content, the professor can create alternative explanations of the same content, demonstrating his/her teaching abilities ${ }^{(14)}$.

Considering that, due to the motivating factors for the beginning of the teaching activity, the complementation of income is of significant importance as a reason for starting the activities, although through the intermediary of one of the interviewees a non-professional perception of teaching, considered as a vocation or mission, observing an early insertion in teaching.

It is necessary that the professor recognizes himself/herself as an education professional and understands that for this professionalization, the development of all Basic Knowledge for Teaching will be required. Just as at the beginning of any professional activity, certain qualifications are required for the area of activity. And, when they entered the teaching, the professors of this study used their previous experiences as students to base their professional practice, demonstrating an absence of the perception of the professionalization of teaching.

When they suddenly inserted themselves in teaching, some professors used the student memories to subsidize their initial practice, and the participants considered that the teaching performance is a reflection of what the professor understands as teaching and that the repetition of models that marked them positively in their student trajectory was an activity that came from private interpretations of what it is to be a good professor (through the use of teaching-learning methodologies and strategies that enabled them to learn). And the way these professors work is often restricted to the reproduction of models that they considered valid (but that may not be assertive) and were previously learned by socialization and exchange, observing professors considered "models" or sharing experiences with colleagues more experienced.

Professor training should be seen as an instrument of teaching professionalization, which allows for the awareness and expansion of the PCK, when it is influenced by the personal and professional trajectory of the professor and his/her reflections from these contexts, as well as his/her perceptions about good professors and models which should be problematized in professor training meetings, providing theoretical support for reflection, appropriation and strengthening of their practices. 
Learning with experienced colleagues, referred to by the participants, even if informal, defined as mentoring, allows the expansion of professor knowledge ${ }^{(10)}$. Using peers to exchange ideas enables the enrichment of the teaching repertoire and consequent strengthening of their pedagogical practices. The mentoring used as a strategy to strengthen the PCK can be formally structured in professor training meetings, since human interaction leads to the process of reflection on the knowledge to practice teaching contributes to the understanding of professional knowledge of professors, with consequent development and expansion of the $\mathrm{PCK}^{(11)}$.

And this direction of actions aiming at the best way of structuring and directing teaching can be the key to the development of the PCK, resulting in a new teaching identity due to the new internalized sense of self $f^{(14)}$.

The responsibility for the pedagogical act and the search for the training for the competent exercise of this action have been attributed to the professors ${ }^{(15)}$. In practice, the absence of training for the teaching profession is observed, concentrating such activities on isolated training throughout the professional trajectory, in which there is no perception of continuous and/ or deliberate training.

The quest for qualification should be a shared activity, understood as a need of the professor and offered by the teaching institution in which the professor works, ideally before starting teaching, to be problematized, among other topics, the main difficulties pointed out by the professors. participants, such as: lack of understanding of PPP, difficulty in using active methods and encouraging student reflection.

New pedagogical practices require new attitudes, and the exercise of reflection itself in action helps to achieve this goal. This daily reflection on the practice itself allows the professor, with his/her critical eye to reality, to perceive his/her needs for improvement and, consequently, to seek permanent professor training, aiming at a more emancipatory teaching, with a more dialogic, problematizing and critical-creative attitude ${ }^{(4)}$. This allows for professor strengthening, when the necessary knowledge for the teaching practice considered as "excellence" is contingently mobilized by the professor from his/her reflection process ${ }^{(4)}$, which can be obtained through constant feedback practices on the pedagogical praxis of professors in professor training meetings. Thus, knowledge for teaching is constructed by reflecting on its own teaching activity, and by re-evaluating it as a reflective agent, the professor seeks to achieve better results, to rebuild and transform his/her $\mathrm{PCK}^{(11)}$.

This process stems from the teaching and learning moments (when the professor reflects on the way in which the meeting was held), the professor training meetings, the mentoring activities and the students' own feedback on the teaching-learning process offered. Providing professor training meetings that provide this awareness and sharing of the conclusions derived from this reflective process strengthens the pedagogical practice ${ }^{(6)}$ through the understanding, acceptance and reflection of the trajectory itself.

The professor's concern related to the conduction of one's own professional development from the proposal of reflection in action, when the professor reflects on his/her performance and seeks strategies to strengthen his/her practice, reflects the awareness that the professor training changes the way of teaching, providing maturity and collective learning ${ }^{(13)}$.

Such professor awareness is important to pursue professional development strategies. Ongoing training is a necessary condition to enable the professor to face the complexity of the content of teaching and to master the explicitness of expert thought, providing important distinctions in the quality of teaching offered ${ }^{(10)}$. This search for professional development suggests a professional maturity and a movement of recognition of professor professionalism, indicating a movement of expansion of the PCK.

In this way, professor training favors the constant revitalization of the teaching-learning process when searching for methodological teaching strategies that transform the educational practice ${ }^{(16)}$.

These transformations are necessary so that the use of the word/ attitude to "absorb" as synonymous with understanding the content by the student, which characterizes banking education, is not found in the professors' discourse and practice. In this, there is preference for the dialogic expositive class, which allows the professor to stay in activities already known, avoiding to explore other possibilities that provide the learning with the active participation of the students. This educator is the transmitter agent of information and knowledge to the students, imposing their knowledge, without space for reflections, depositing and transferring what he knows ${ }^{(17)}$.

These are common practices of novice professors when they feel insecure and use teaching strategies that make students' reflection unfeasible, so as not to awaken alternative points of view in areas unknown to professor knowledge, in other words, professor behavior is closely linked to the knowledge of the associated content to the expression of their PCK and their particular mode of teaching ${ }^{(9)}$.

It is necessary for this professor to appropriate the specific knowledge of active teaching and learning methodologies, which allow the connection between education and practice. Thus, the School also becomes responsible for promoting human development, by encouraging the complexity of thoughts and actions.

This is one of the main challenges for excellence in teaching: to prepare creative, intelligent, responsible and problemsolving students. The use of active learning methodologies can contribute to the achievement of these purposes ${ }^{(6)}$.

Encouraging dialogue and listening to the student enables meaningful learning, however, it is observed in practice that the most important challenge of teaching is that some professors believe they have been hired to speak, when in fact, the learn to listen to students ${ }^{(6)}$.

It is the professor's job to intervene in this meaningful process of learning, in which openness to dialogue is a challenge to be faced in reflexive pedagogical practice, which should encourage the student's curiosity, orienting him/her to new discoveries, encouraging his/her autonomy and the development of more critical and reflexive attitudes in the course of their training ${ }^{(18)}$.

At the professor training meetings, in addition to the active methodologies, it is essential that the professor knows the curriculum of the course in which he/she works, so that he/she can strengthen his/her PCK and carry out the disciplinary integration with a encouragement to the critical reflection of the student. Lack of knowledge of the curriculum is one of the main difficulties encountered in the initial practice of novice professors when their 
initial training did not help them to think about the curriculum from a broader perspective ${ }^{(14)}$. This need to know and evaluate the curriculum can help in the development of a critical reflection on the formative objectives and the organization of the disciplines and menus, providing the professor understanding about the relation of its contents to be taught with the curriculum ${ }^{(6)}$.

Thus, it is understood that the period for initial training is not sufficient for the professor to understand the broad context that encompasses the teaching performance and the knowledge necessary for the professionalization of teaching. It is necessary that professors know in detail the processes of school organization and management and their institutional and political dimensions, as well as how these elements can influence the teaching and learning process and the training of students ${ }^{(19)}$.

Therefore, the participants of this study understand that, in addition to mastery and knowledge of content, it is necessary to know the teaching and learning methods, and these have been apprehended in professor training meetings or through the repetition of models experienced in their own training, as well as the practice of mentoring. These behaviors can strengthen professional practice, but they do not substitute for specific professor training and the need to know the educational context in which professors are inserted. There is concern about the conduct of personal professional development only from reflection on action, which should be allied to the search for strengthening its practices. During this course, the educator is expected to become a critical, creative and reflective provider who can provide his/ her students with training that encourages them in the same way.

\section{Study limitations}

The main limitations relate to the lack of studies with the same target population, which made it impossible to reach broad issues or in other contexts. This lack was evidenced by the authors' review for the theoretical basis and analysis of the data of this study. The exploratory nature is also limiting in terms of literature review and comparison of results with other studies.

It is also observed that the data collection meetings, characterized as professor training meetings, provided opportunities for reflection, socialization and learning among the present peers, not having a direct reach to other professors who did not participate in the study.

\section{Contributions to the sector of nursing}

The importance of the pedagogical training of the nurses in their initial training, together with the processes of permanent professor training for educators in the pedagogical projects of the schools is discussed, because they want providers that are competent, critical, creative, innovative and who can face the challenges of the world of work. Thus, fostering and discussing the need for sound professor education in order to re-signify their own educational process and their way of teaching in secondary technical teaching is an imperative of the new demands in nursing and nursing education.

\section{FINAL CONSIDERATIONS}

Among the Base Knowledge for Teaching, Content Knowledge appears as a priority for the development of pedagogical preparation for teaching, used to overcome the lack of pedagogical knowledge and to subsidize the initial teaching practice of the participants of this study.

In addition to the strong anchoring of the Content Knowledge, the learning with colleagues was pointed out by the study participants as a strategy used to strengthen the preparation for teaching and to overcome the incipience of the initial training.

Participants reported on the importance of professor training (by attending specific courses and participating in pedagogical training) and the use of the experiences experienced in their training processes. They also pointed out the need for Permanent Education offered by the institution of education in which they work, knowledge and approximation to the PPP and the Pedagogical Course Project (PCP) and training for the use of active teaching and learning methodologies, thus valuing the training with the recognition of the professionalization of teaching, indicating a movement of expansion of the PCK.

It is considered that, in exercising good teaching practices, the professor contributes to the qualification and strengthening of Nursing, enabling professional recognition and appreciation. In order to constitute the indispensable attributes for the training of nurses, this provider must remember the importance of personal search, and not only design for the undergraduate degree and the schools of action the responsibility for their development and qualification of the professor. Their personal dimension should be encouraged by allowing themselves to look at new possibilities and learn to learn, becoming a critical, creative and reflective providers and, in this two-way street, to learn as you teach.

\section{ACKNOWLEDGMENT}

Thank the support of the University Scholarship Program of Santa Catarina state (UNIEDU Program).

\section{REFERENCES}

1. Coloni CSM, Teixeira VM, Moreira MCO, Piotto R, Góes FSN, Camargo RAA. Pedagogical practice in mid-level professional nursing education. Cogitare Enferm[Internet]. 2016[cited 2017 Jan 23];21(1):1-9.Available from: http://www.saude.ufpr.br/portal/ revistacogitare/wp-content/uploads/sites/28/2016/10/42026-171300-1-PB.pdf

2. Marin MJS, Tonhom SFR, Michelone APC, Higa EFR, Bernardo MCM, Tavares CMM. Projections and expectations of students enrolled in a teaching qualification in a technical health professional education course. Rev Esc Enferm USP[Internet]. 2013[cited 2017 Jan 12];47(1):217-24. Available from:http://www.scielo.br/pdf/reeusp/v47n1/en_a28v47n1.pdf 
3. Machado $\mathrm{MH}$, Wermelinger M, Vieira M, Oliveira E, Lemos W, Aguiar Filho W, et al. Aspectos gerais da formação da enfermagem: o perfil da formação dos enfermeiros técnicos e auxiliares. Enferm Foco[Internet] 2016[cited 2017 Jan 23];6(2/4):15-34. Available from: http://revista.portalcofen.gov.br/index.php/enfermagem/article/view/687/297

4. Backes VMS, Moya JLM, Prado ML, Menegaz JC, Cunha AP, Francisco BF. Expressions of pedagogical content knowledge of an experienced nursing teacher. Texto Contexto Enferm[Internet]. 2013[cited 2017 Jan 23];22(3):804-10. Available from: http://www. scielo.br/pdf/tce/v22n3/en_v22n3a29.pdf

5. Bião e Silva ACA, Silva GTR, Silva RMO, Vieira SL, Santana MS. Secondary professional education: characterization of scientific production in graduate studies. Acta Paul Enferm[Internet]. 2013[cited 2017 Jan 12];26(5):499-505. Available from: http://www. scielo.br/pdf/ape/v26n5/a15v26n5.pdf

6. Shulman LS. Conocimiento y enseñanza: fundamentos de la Nueva Reforma. Profesorado[Internet]. 2005;9(2):1-30. Available from: https://www.ugr.es/ recfpro/rev92ART1.pdf

7. Marcon D, Graça ABS, Nascimento JV. [Context knowledge in the initial training in physical education]. Rev Bras Educ Fís Esporte[Internet]. 2013[cited 2017 Jul 20];27(4):633-45. Available from: http://www.scielo.br/pdf/rbefe/v27n4/v27n4a11.pdf [Portuguese]

8. Minayo MCS, (Org.). Pesquisa Social: teoria, método e criatividade. Rio de Janeiro: Vozes; 2012.

9. Shulman LS. [Those who understand: knowledge growth in teaching]. Educ Res[Internet]. 1986[cited 2018 Feb 01];15(5):04-14. Available from: http://www.fisica.uniud.it/URDF/masterDidSciUD/materiali/pdf/Shulman_1986.pdf [Portuguese]

10. Backes VMS, Moya JLM, Prado ML. The construction process of pedagogical knowledge among nursing professors. Rev LatinoAm Enfermagem[Internet]. 2011[cited 2017 Jan 12];19(2):421-8. Available from: http://www.scielo.br/pdf/rlae/v19n2/pt_26.pdf

11. Marcon D, Graça ABS, Ramos V, Milistetd M, Nascimento JV. O conhecimento do contexto na construção do conhecimento pedagógico do conteúdo dos futuros professores de educação física. Pensar Prát[Internet]. 2016[cited 2017 Jan 15];19(3):522-32. Available from https://www.revistas.ufg.br/fef/article/view/34641/pdf

12. Menegaz JC, Backes VMS. Good professors of nursing, medicine, and dentistry: perception on the knowledge of learners. Esc Anna Nery Rev Enferm[Internet]. 2016[cited 2017 Jan 15];20(2):268-74. Available from:http://www.scielo.br/pdf/ean/v20n2/14148145-ean-20-02-0268.pdf

13. Souza DM, Backes VMS, Prado ML. [Teacher training in professional education technique middle level: an integrative literature review]. Interfaces Educ[Internet].2016[cited 2017 Jan 23];7(20):211-35. Available from: https://periodicosonline.uems.br/index. php/interfaces/article/view/987 Portuguese

14. Gudmundsdóttir S, Shulman LS. Conocimiento didáctico en ciencias sociales. Profesorado [Internet]. 2005 [cited 2018 Feb 01];9(2):01-12. Available from: https://www.ugr.es/ recfpro/rev92ART5.pdf

15. Meira MDD, Kurcgant P. Nursing education: training evaluation by graduates, employers and teachers. Rev Bras Enferm[Internet]. 2016[cited 2017 Jan 23];69(1):10-5. Available from: http://dx.doi.org/10.1590/0034-7167.2016690102i

16. Spagnol CA, Monteiro LAS, Paula CL, Bastos JM, Honorato JAG. Experiencing conflict situations in the context of nursing: the use of sketch as a teaching-learning strategy. Esc Anna Nery Rev Enferm[Internet]. 2013[cited 2017 Jan 15];17(1):184-9. Available from: http://www.scielo.br/pdf/ean/v17n1/26.pdf

17. Freire P. Pedagogia da autonomia: saberes necessários à prática educativa. Rio de Janeiro: Paz e Terra; 2014.

18. Lima MM, Reibnitz KS, Kloh D, Vendruscolo C, Correa AB. Dialogue: network that intertwines the pedagogical relationship in to the practical-reflective teaching. Rev Bras Enferm[Internet]. 2016[cited 2017 Jan 15];69(4):610-7. Available from: http://dx.doi. org/10.1590/0034-7167.2016690406i

19. Marcon D, Graça ABS, Nascimento JV. [Reinterpretation of the theoretical conceptual framework of pedagogical content knowledge]. Rev Bras Educ Fís Esp[Internet]. 2011[cited 2017 Jan 23];25(01):323-29. Disponível em: http://www.scielo.br/pdf/rbefe/v25n2/13 Portuguese 